\title{
Green Fertilization Enhances the Photosynthetic Performance and the Growth of Leguminous Trees for Restoration Plantation in Central Amazon
}

\author{
Roberto Kirmayr Jaquetti ${ }^{1}$, José Francisco de Carvalho Gonçalves ${ }^{1 *}$, \\ João Baptista Silva Ferraz ${ }^{2}$, Marciel J. Ferreira'2 ${ }^{2}$ Ulysses Moreira dos Santos Junior ${ }^{1}$, \\ Claudivan Feitosa de Lacerda $^{3}$ \\ ${ }^{1}$ Laboratory of Plant Physiology and Biochemistry, National Institute of Amazonian Research, \\ Manaus, Brazil \\ ${ }^{2}$ National Institute of Amazonian Research, Manaus, Brazil \\ ${ }^{3}$ Forest Science Department, Federal University of Amazon, Manaus, Brazil \\ Email: ${ }^{*}$ jfc@inpa.gov.br, roberto.kirmayr@hotmail.com, jferraz@inpa.gov.br, marciel@ufam.edu.br
}

Received 1 May 2014; revised 15 June 2014; accepted 16 July 2014

Copyright (C) 2014 by authors and Scientific Research Publishing Inc.

This work is licensed under the Creative Commons Attribution International License (CC BY).

http://creativecommons.org/licenses/by/4.0/

(c) (i) Open Access

\section{Abstract}

The leguminous tree species Dipteryx odorata (Aubl.) Willd. and Inga edulis Mart. were grown in the field to reforest a degraded area. To investigate the photosynthetic responses and the initial growth of Amazonian forest species under fertilization, the study species were subjected to different treatments: $\mathrm{T} 1=$ unfertilized-control, $\mathrm{T} 2$ = chemical fertilization, $\mathrm{T} 3$ = green fertilization and T4 = green and chemical fertilization. $D$. odorata showed the highest absolute growth rates in height under treatments T4 $\left(10.2 \mathrm{~cm} \cdot \mathrm{month}^{-1}\right)$ and T2 $\left(12.2 \mathrm{~cm} \cdot \mathrm{month}^{-1}\right)$. I. edulis exhibited the best performance for this same parameter in $\mathrm{T} 4\left(23.0 \mathrm{~cm} \cdot \mathrm{month}^{-1}\right)$. The highest photosynthesis values $\left(P_{\mathrm{n}}\right)$ for both $D$. odorata $\left(13.1 \mu \mathrm{mol} \cdot \mathrm{m}^{-2} \cdot \mathrm{s}^{-1}\right)$ and $\mathrm{I}$. edulis $\left(20.6 \mu \mathrm{mol} \cdot \mathrm{m}^{-2} \cdot \mathrm{s}^{-1}\right)$ were found in T4. The two species also showed the highest performance index values $\left(\mathrm{PI}_{\mathrm{ABS}}\right)$ under $\mathrm{T} 4(\mathrm{D}$. odora$t a=2.9$ and $\mathrm{I}$. edulis $=5.2$ ). Our results suggest that the combination of green and chemical fertilization was the most effective of the four treatments evaluated for improving the photosynthetic performance and the growth of both species during the initial establishment of the species in a degraded area.

\section{Keywords}

Photosynthesis, Chlorophyll $a$ Fluorescence, Chloroplastid Pigment Contents,

${ }^{*}$ Corresponding author.

How to cite this paper: Jaquetti, R.K., et al. (2014) Green Fertilization Enhances the Photosynthetic Performance and the Growth of Leguminous Trees for Restoration Plantation in Central Amazon. American Journal of Plant Sciences, 5, 24972508. http://dx.doi.org/10.4236/ajps.2014.516264 


\section{Introduction}

Concern about the need to restore degraded ecosystems in the Amazon rainforest has increased in recent years. Currently, 20\% of the cover of the Brazilian Amazon forest has been altered [1]. The situation found in these areas differs from that of the original ecosystem, and the current environmental conditions are generally unfavorable for the development of native species [2]-[4] as biotic and abiotic stresses are relatively intense and frequent [5]. In degraded areas, the availability of water and nutrients is greatly reduced [6], and excessive irradiance, if not efficiently used or dispersed, can cause severe damage to the photosynthetic machinery of the species present [7]. Physiological stress factors, such as drought, high irradiance and low nutrient availability, are frequently responsible for decreased photosynthesis and the resulting decrease in growth [8]-[11].

Nutrient limitation in the soil can also compromise the growth of plant species because nutrients such as N, P, $\mathrm{K}, \mathrm{Ca}$ and Mg perform vital functions related to the process of photosynthesis and the maintenance of the plants' water homeostasis [12] [13]. An adequate supply of nutrients can also promote improved rates of photosynthesis and facilitate the growth of plants in additional ways [6]. Certain nutrients, such as $\mathrm{K}$, Ca and Mg, may also promote tolerance to abiotic stresses [9] [12].

Rapid growth and high shoot biomass production are fundamental traits needed by species to achieve success in a forest plantation whose purpose is ecological restoration [4]. Therefore, the use of leguminous woody species for ecological restoration is highly recommended because many of them are pioneer and initial secondary species and have been successfully used for the revegetation of arid and nutrient-deficient ecosystems. The greater competitive ability of leguminous species in sites with low resource levels can be attributed, in part, to their ability to form symbioses with N-fixing bacteria [14].

The study of physiological parameters (gas exchange, chlorophyll $a$ fluorescence and pigment content) in field experiments can be used to understand the functioning of ecosystems and species, and the ways in which factors interact with each other [13]. This knowledge can help us to develop effective restoration strategies that consider the quality of the habitat relative to the performance of each individual. However, these parameters have rarely been used in the field of ecological restoration, particularly for forest species in the tropics [15]. Chlorophyll $a$ fluorescence and pigment content analysis may be good indicators of physiological stress in plants under high irradiance [7] [16]-[18] and can be used to evaluate the acclimation capacity of species in degraded areas [3] [4] [19].

Dipteryx odorata (Aubl.) Willd. and Inga edulis Mart. are native to the study region and are usually used in forest plantations for timber or to reclaim soil fertility [20] [21]. We tested the hypothesis that the photosynthetic structure and function of these species would be improved by a combination of fertilization treatments rather than by individual applications of treatments, e.g., Ferreira et al. [19]. Thus, the aim of the present work was to investigate the influence of various fertilization treatments on the growth and photosynthetic responses (gas exchange, chlorophyll $a$ fluorescence and contents of chlorophylls and carotenoids) of two leguminous tree species in a field experiment for the reforestation of a degraded area.

\section{Materials and Methods}

\subsection{Study Site and Planting}

The study was conducted in a degraded area near the Balbina hydroelectric dam ( $01^{\circ} 55^{\prime} 99^{\prime \prime S}$ and $\left.59^{\circ} 24^{\prime} 65^{\prime \prime} \mathrm{W}\right)$ in the county of Presidente Figueiredo, AM. This area was degraded at the time of the dam construction. The regional vegetation is characterized as "non-flooded dense forest". According to the Köppen climate classification system, the climate of the region is Af (tropical humid), with a mean annual temperature above $25^{\circ} \mathrm{C}$ and an annual precipitation of $2280 \mathrm{~mm}$. Relatively less rain falls between July and September $\left(<100 \mathrm{~mm} \cdot \mathrm{month}^{-1}\right)$. The most common soil in the region is a yellow oxisol with high acidity and low natural fertility [22]. The forest cover in the area has been completely removed, but the top soil was left in place. After 25 years of abandonment, several vegetation islands have appeared as a result of natural regeneration, but most of the area still lacks vegetation cover. The natural regeneration present in the area is dominated by the species Vismia spp., Bellucia sp., 
Cecropia sciadophylla and Byrsonima crassifolia.

The experiment was initiated in December 2010, at the beginning of the season of relatively high precipitation. The preparation of the site began with manually excavating $30 \times 30 \times 40 \mathrm{~cm}$ holes for tree planting. Fifty grams of lime and $150 \mathrm{~g}$ of the chemical fertilizer Fosmag ${ }^{\circledR}$ (4\% N, 14\% P, 7\% K, 11.5\% Ca, 2.7\% Mg, 10.4\% S, 0.07\% $\mathrm{B}, 0.59 \% \mathrm{Zn}$ and $0.15 \% \mathrm{Cu}$ ) were then incorporated in all fertilization treatments except for T1. The spacing of the planted seedlings was $2 \times 2 \mathrm{~m}$. Seedlings were selected from the greenhouse based on the criteria of uniform size and health of individuals within the same species (35 cm height for D. odorata and $40 \mathrm{~cm}$ for I. edulis). The following fertilization treatments were used: T1) unfertilized-control, T2) chemical fertilization with $150 \mathrm{~g}$ of Fosmag $^{\circledR}$ (the same formulation specified above) and $50 \mathrm{~g}$ of lime, T3) green fertilization with branches and leaves from the surrounding secondary forest and T4) both chemical and green fertilizer applied together. The chemical fertilization treatments (T2 and T4) received 2 applications performed 4 months and 8 months after planting and applied in an area $50 \mathrm{~cm}$ in diameter around the seedlings. The treatments with green fertilization (T3 and T4) also received 2 applications: one at the moment of planting, with $12.45 \mathrm{~kg} \cdot \mathrm{m}^{-2}$ of fresh mass or 6.78 $\mathrm{kg} \cdot \mathrm{m}^{-2}$ dry mass, and another 4 months later, with $5.52 \mathrm{~kg} \cdot \mathrm{m}^{-2}$ of fresh mass or $3.07 \mathrm{~kg} \cdot \mathrm{m}^{-2}$ dry mass. The macro- and micronutrient concentrations in the dry plant material (branches and leaves) used in T3 and T4 were as follows: $481.1 \mathrm{~g} \cdot \mathrm{kg}^{-1} \mathrm{C}, 10.7 \mathrm{~g} \cdot \mathrm{kg}^{-1} \mathrm{~N}, 0.4 \mathrm{~g} \cdot \mathrm{kg}^{-1} \mathrm{P}, 3.9 \mathrm{~g} \cdot \mathrm{kg}^{-1} \mathrm{~K}, 5.3 \mathrm{~g} \cdot \mathrm{kg}^{-1} \mathrm{Ca}, 1.5 \mathrm{~g} \cdot \mathrm{kg}^{-1} \mathrm{Mg}, 244.2 \mathrm{mg} \cdot \mathrm{kg}^{-1}$ Fe and $23.7 \mathrm{mg} \cdot \mathrm{kg}^{-1} \mathrm{Zn}$.

\subsection{Survival and Growth Analysis}

Establishment of the species was determined by the percentage of live plants 10 months after planting. The growth of the species was evaluated by determining the absolute growth rates (AGR) of dimensions such as height and diameter. The stem length (SL) and diameter at ground level (DGL) data were collected in two stages with five replicates per treatment $(n=5)$. The first measurement occurred in January 2011, and the second was performed 10 months after the first. The absolute growth rates in height (AGR-h) and diameter (AGR-d) were determined as in Hunt [23].

$\mathrm{CO}_{2}$ and water-vapor exchanges were measured between 8:00 and 11:00 h in 5 selected plants per treatment 10 months after the plantings. A fully expanded healthy leaf that was also exposed to the sun was selected on each plant. The net photosynthetic rate $\left(P_{\mathrm{n}}\right)$, dark respiration $\left(R_{\mathrm{d}}\right)$, transpiration rate $(E)$ and stomatal conductance $\left(g_{\mathrm{s}}\right)$ were measured using a portable open $\mathrm{CO}_{2}$ and water-vapor exchange system with an infrared gas analyzer (Portable Photosynthesis SystemLI-6400, LI-COR Inc., Lincoln, NE, USA) as described by Santos Junior et al. [4]. Each measurement for the above parameters was determined based on photosynthetic photon-flux densities (PPFD) of 0 and $1000 \mu \mathrm{mol} \cdot \mathrm{m}^{-2} \cdot \mathrm{s}^{-1}$, with the foliar chamber adjusted for a $\mathrm{CO}_{2}$ concentration, temperature and water-vapor concentration of $380 \pm 4 \mu \mathrm{mol} \cdot \mathrm{mol}^{-1}, 31^{\circ} \mathrm{C} \pm 1{ }^{\circ} \mathrm{C}$ and $21 \pm 1 \mathrm{mmol} \cdot \mathrm{mol}^{-1}$, respectively.

\subsection{Determination of the Chloroplast Pigments}

Following the $\mathrm{CO}_{2}$ and water-vapor exchange readings, the same leaves were collected for Chl and carotenoid (Car) pigment analysis. These analyses were performed using $0.1 \mathrm{~g}$ of fresh material ground in $10 \mathrm{ml}$ of $80 \%$ acetone and magnesium carbonate $\left(\mathrm{MgCO}_{3}\right)$ with $10 \mathrm{ml}$ of $100 \%$ acetone added immediately following the initial grinding step. The suspension was filtered, and the absorbance was read at $663 \mathrm{~nm}(\mathrm{Chl} a), 645 \mathrm{~nm}(\mathrm{Chlb})$ and $480 \mathrm{~nm}$ (Car) using a spectrophotometer (Ultrospec 2100 pro UV/visible, Amersham Biosciences, Cambridge, UK) [24].

Chlorophyll a fluorescence was measured with a portable fluorometer (Handy PEA, Hansatech, Norfolk, UK) on the same individuals and leaves used for the gas-exchange measurements in each treatment. The completely expanded and healthy leaves selected were adapted to a dark period of $30 \mathrm{~min}$, sufficient for the complete oxidation of the photosynthetic electron-transport system. The adaxial leaf side was then exposed to a $1 \mathrm{~s}$ excitation pulse of high irradiance $\left(3,000 \mu \mathrm{mol} \cdot \mathrm{m}^{-2} \cdot \mathrm{s}^{-1}\right)$ with a wavelength of $650 \mathrm{~nm}$. The measurements were conducted between 9:00 and 12:00 h. A performance index $\left(\mathrm{PI}_{\mathrm{ABS}}\right)$, which combines the parameters of energy conservation from photons absorbed by the photosystem II antenna and the reduction of $\mathrm{Q}_{\mathrm{B}}$, was calculated based on absorption ( $\left.\mathrm{PI}_{\mathrm{ABS}}\right)$, as described by Srivastava et al. [25] and Gonçalves \& Santos Junior [3].

\subsection{Experimental Design and Statistical Analysis}

The experimental design consisted of randomized blocks with 5 repetitions $(n=5)$. The 8 treatments involved a 
combination of 2 factors (4 fertilization treatments and 2 species). The data were analyzed using a two-way ANOVA, and the means were separated based on Duncan's test $(\mathrm{p}<0.05)$ with the statistical program STATISTICA 7.0 (StatSoft Inc., Tulsa, OK, USA).

\section{Results and Discussion}

\subsection{Survival and Growth Analysis}

D. odorata showed $100 \%$ survival in all fertilization treatments, where as I. edulis showed $100 \%$ survival in T1 and T2, 94\% in T3 and 83\% in T4 (Table 1).

The survival of seedlings in the field is related to the capacity of the species to resist the stress factors in a degraded area. This survival capacity determines the success of a forest plantation for both commercial and ecological restoration purposes [4] [26]. The high survival rates of the species in this experiment can be explained, in part, by factors such as: a) the time of data collection, as older plantings are subject to higher mortality rates [2] [27]; and b) the planting period (the beginning of the rainy season), which provides milder conditions for early seedling development. Both species appear to have developed several characteristics that facilitate survival under the adverse conditions found in a degraded area, particularly in the face of nutritional deficiencies. This ability was marked in $D$. odorata, which did not show extensive development in T1 but still had no mortality.

The values of the percentage of survival for $D$. odorata in this study were higher than those found by Souza et al. [28] in a 6-year-old mixed plantation in the Manaus region in full sunlight (86\%) and shade conditions (83\%). This high survival percentage appears to be characteristic of the species because Souza et al. [29] also found 91.7\% and 80.6\% survival after 3 and 11 years, respectively, in an ecological forest plantation, and Tonini et al. [30] found 92.0\% survival after 6 years in a commercial plantation. I. edulis showed survival rates similar to those found by several previous studies. Nichols et al. [31] observed 97\% survival of I. edulis interplanted with Terminalia amazonia at 2 years in a mixed plantation in Costa Rica. Santos Junior et al. [4] found that the survival of $I$. edulis after planting was greater than $95 \%$ during the restoration of a degraded area damaged by oilretrieval activity in the Amazon.

Both species and fertilization treatments had significant effects on both absolute growth rate in height (AGR-h) and diameter (AGR-d). D. odorata reached the highest values of AGR-h in T2 (12.2 $\left.\mathrm{cm}^{\circ} \mathrm{month}^{-1}\right), 13$ times greater than that in T1 (Figure 1). The species I. edulis had the highest AGR-h in T4 $\left(23.0 \mathrm{~cm} \cdot \mathrm{month}^{-1}\right)$, which was 7 times greater than that in T1 (Figure 1). The growth of I. edulis was higher than that of D. odorata in all fertilization treatments.

The absolute growth rates in diameter (AGR-d) for D. odorata were the greatest in T2 and T4 (1.5 and 1.3 $\mathrm{mm} \cdot \mathrm{month}^{-1}$, respectively) (Figure 1). For I. edulis, the best treatments were T3 and T4 with mean AGR-d values of 5.3 and $6.0 \mathrm{~mm} \cdot \mathrm{month}^{-1}$, respectively (Figure 1). Of the two species, I. edulis showed greater values of AGR-d in all fertilization treatments.

\begin{tabular}{|c|c|c|}
\hline Species & Fertilization & Survival (\%) \\
\hline \multirow{4}{*}{ Dipteryx odorata } & $\mathrm{T} 1$ & 100.00 \\
\hline & $\mathrm{T} 2$ & 100.00 \\
\hline & T3 & 100.00 \\
\hline & $\mathrm{T} 4$ & 100.00 \\
\hline \multirow{4}{*}{ Inga edulis } & $\mathrm{T} 1$ & 100.00 \\
\hline & $\mathrm{T} 2$ & 100.00 \\
\hline & T3 & 94.44 \\
\hline & $\mathrm{T} 4$ & 83.33 \\
\hline
\end{tabular}




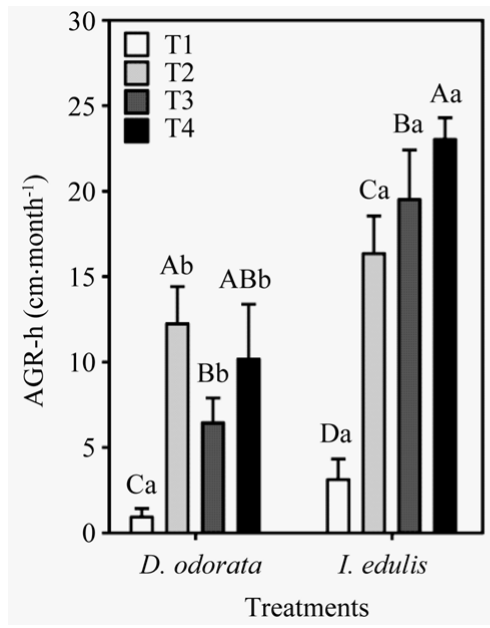

(a)

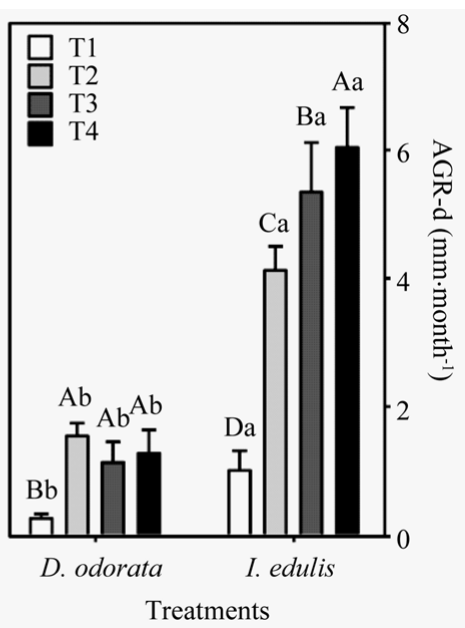

(b)

Figure 1. Absolute growth rate in height (AGR-h) (a) and in diameter (AGR-d) (b) of two leguminous tree species, Dipteryx odorata and Inga edulis, in an ecological restoration planting in a degraded area near Balbina hydroelectric dam (PresidenteFigueiredo, AM). T1 = no fertilization, T2 = chemical fertilization, $\mathrm{T} 3$ = green fertilization, $\mathrm{T} 4$ = green and chemical fertilization.

Table 2 shows the ANOVA results for the analyzed parameters. A significant effect was observed for all growth parameters for both fertilization and species, and the interaction between the factors was also significant.

D. odorata appeared to show a major growth limitation related to nutritional deficiency (Table 3), primarily for P because certain nutrients can become unavailable under green fertilization [32]. The growth of I. edulis appears to have been limited by nutritional status as well as by hydric constraints. This limitation is evident from a comparison of the green fertilization with the other treatments. Additionally, I. edulis produced an extensive net of fine roots in the upper soil layer under the green fertilization treatments (unpublished data). This root network may have allowed better water and nutrient absorption, directly affecting the growth of the species, and it is likely that this response represents one of the reasons that T3 and T4 were more effective in I. edulis than in $D$. odorata. Such responses could represent different strategies developed by distinct successional groups to overcome the limitations imposed by the environmental conditions. The superiority of the initial growth of $I$. edulis to that of $D$. odorata can also be explained because $I$. edulis is a fast-growing species that colonizes altered areas. Despite the high survival percentage found for $D$. odorata in a forest plantation near the Manaus region, the growth of this species was less than that of most of the native species tested by Souza et al. [29].

The results of this study are consistent with several published findings for the same species. For $D$. odorata, Souza et al. [28] observed an increase in height and diameter of $11.6 \mathrm{~cm} \cdot \mathrm{month}^{-1}$ and $0.92 \mathrm{~mm} \cdot \mathrm{month}^{-1}$ to 6 years of age in a full-sunlight planting with a manure pit. Joslin et al. [27] have found that $I$. Edulis showed an average growth in height of $22.5 \mathrm{~cm} \cdot \mathrm{month}^{-1}$ and $12.5 \mathrm{~cm} \cdot \mathrm{month}^{-1}$ with a P and $\mathrm{K}$ supply and unfertilized, respectively. These results confirm the nutrient limitation of the species. The growth in height found by Santos Junior et al. [4] 2 months after planting was $5.1 \mathrm{~cm} \cdot \mathrm{month}^{-1}$, less than the value found under most treatments in this study.

\section{2. $\mathrm{CO}_{2}$ and Water-Vapor Exchanges}

For $D$. odorata, the $P_{\mathrm{n}}$ values were greater in treatments $\mathrm{T} 2$ and T3, reaching the highest values in treatment T4 $\left(13.1 \mu \mathrm{mol} \cdot \mathrm{m}^{-2} \cdot \mathrm{s}^{-1}\right)$, which showed values $73 \%$ higher than the control (T1) (Table 4). The same was the case for I. edulis, which showed the highest $P_{\mathrm{n}}$ values in T4 $\left(20.6 \mu \mathrm{mol} \cdot \mathrm{m}^{-2} \cdot \mathrm{s}^{-1}\right), 70 \%$ higher than T1. I. edulis presented higher $P_{\mathrm{n}}$ values than $D$. odorata in all fertilization treatments (Table 4).

No significant differences among the fertilization treatments were found for $R_{\mathrm{d}}$ in $D$. odorata, which showed values ranging from 0.5 to $1.0 \mu \mathrm{mol} \cdot \mathrm{m}^{-2} \cdot \mathrm{s}^{-1}$ between T4 and T1, respectively (Table 4). I. edulis showed the lowest $R_{\mathrm{d}}$ values in T2 and the highest in T1. In general, D. odorata showed lower $R_{\mathrm{d}}$ values than $I$. edulis. The 
Table 2. ANOVA results (F values) $(n=5)$ for the factors Species and Fertilization and the interaction between the factors (Sp. X Fert.). Parameters: Absolute growth rate in height (AGR-h), absolute growth rate in diameter (AGR-d), net photosynthetic rate $\left(P_{\mathrm{n}}\right)$, dark respiration $\left(R_{\mathrm{d}}\right)$, stomatal conductance $\left(g_{\mathrm{s}}\right)$, transpiration rate $(E)$, maximum photochemical efficiency $\left(\mathrm{F}_{\mathrm{v}} / \mathrm{F}_{\mathrm{m}}\right)$, performance index ( $\left.\mathrm{PI}_{\mathrm{ABS}}\right)$, chlorophyll $a(\mathrm{Chl} a)$, chlorophyll $b(\mathrm{Chl} b)$, carotenoids (Car), chlorophyll $(a+b)(\mathrm{Chl}(a$ $+b)$ ), chlorophyll $a / b(\mathrm{Chl} a / \mathrm{Chl} b)$ and chlorophyll $(a+b) /$ carotenoids (Chl $(\mathrm{a}+\mathrm{b}) / \mathrm{Car})$ in a degraded area near Balbina hydroelectric dam after the application of the fertilization treatments.

\begin{tabular}{cccc}
\hline Parameters & Species & Fertilization & Sp X Fert. \\
\hline AGR-h & $105.8^{* *}$ & $75.4^{* *}$ & $12.7^{* *}$ \\
AGR-d & $505.9^{* *}$ & $97.1^{* *}$ & $43.7^{* *}$ \\
$\boldsymbol{P}_{\mathbf{n}}$ & $85.2^{* *}$ & $11.5^{* *}$ & $0.8^{\mathrm{ns}}$ \\
$\boldsymbol{R}_{\mathbf{d}}$ & $38.0^{* *}$ & $4.6^{* *}$ & $1.2^{\mathrm{ns}}$ \\
$\boldsymbol{g}_{\mathbf{s}}$ & $123.9^{* *}$ & $6.4^{* *}$ & $2.7^{*}$ \\
$\boldsymbol{E}$ & $103.6^{* *}$ & $3.3^{*}$ & $1.1^{\mathrm{ns}}$ \\
$\mathbf{F}_{\mathbf{v}} / \mathbf{F}_{\mathbf{m}}$ & $0.7^{0.41}$ & $13.8^{* *}$ & $7.4^{* *}$ \\
$\mathbf{P I} \mathbf{A B s}_{\mathbf{A s}}$ & $8.0^{* *}$ & $4.2^{* *}$ & $1.5^{\mathrm{ns}}$ \\
$\mathbf{C h l} \boldsymbol{b}$ & $0.3^{\mathrm{ns}}$ & $5.7^{* *}$ & $0.2^{\mathrm{ns}}$ \\
$\mathbf{C h l}(\boldsymbol{a}+\boldsymbol{b})$ & $1.2^{\mathrm{ns}}$ & $8.7^{* *}$ & $0.9^{\mathrm{ns}}$ \\
$\mathbf{C a r}$ & $2.2^{\mathrm{ns}}$ & $4.2^{* *}$ & $1.3^{\mathrm{ns}}$ \\
$\mathbf{C h l} \boldsymbol{a} / \mathbf{C h} \boldsymbol{b}$ & $14.1^{* *}$ & $1.4^{\mathrm{ns}}$ & $0.7^{\mathrm{ns}}$ \\
$\mathbf{C h l}(\boldsymbol{a}+\boldsymbol{b}) / \mathbf{C a r}$ & $0.1^{\mathrm{ns}}$ & $5.8^{* *}$ & $3.5^{*}$ \\
\hline
\end{tabular}

${ }^{*}$ Significant at $\mathrm{p}<0.05,{ }^{* *}$ significant at $\mathrm{p}<0.01, \mathrm{~ns}=$ not significant.

Table 3. Concentrations of soil macronutrients (C, N, P, K, Ca and Mg) in a forest plantation with leguminous trees in a degraded area near the Balbina hydroelectric dam, after fertilization treatment application. Mean of 10 samples ( \pm SD).

\begin{tabular}{|c|c|c|c|c|c|c|c|}
\hline \multirow{3}{*}{ Fertilization } & \multirow{2}{*}{ Depth } & \multicolumn{6}{|c|}{ Parameter } \\
\hline & & $\mathrm{C}$ & $\mathrm{N}$ & $\mathrm{P}$ & $\mathrm{K}$ & $\mathrm{Ca}$ & $\mathrm{Mg}$ \\
\hline & \multirow{2}{*}{$\frac{\mathrm{cm}}{0-2.5}$} & \multicolumn{2}{|c|}{$\left[\mathrm{g} \cdot \mathrm{kg}^{-1}\right]$} & \multicolumn{2}{|c|}{$\left[\mathrm{mg} \cdot \mathrm{kg}^{-1}\right]$} & \multicolumn{2}{|c|}{$\left[\mathrm{cmol} \cdot \mathrm{kg}^{-1}\right]$} \\
\hline \multirow{4}{*}{ T1 } & & $6.9 \pm 1.3^{\mathrm{B}}$ & $0.4 \pm 0.1^{\mathrm{B}}$ & $0.2 \pm 0.1^{\mathrm{D}}$ & $6.3 \pm 1.1^{\mathrm{B}}$ & $0.2 \pm 0.1^{\mathrm{C}}$ & $0.2 \pm 0.1^{\mathrm{C}}$ \\
\hline & $2.5-7.5$ & $6.8 \pm 1.4^{\mathrm{B}}$ & $0.4 \pm 0.1^{\mathrm{C}}$ & $0.2 \pm 0.1^{\mathrm{B}}$ & $6.2 \pm 0.9^{\mathrm{C}}$ & $0.1 \pm 0.0^{\mathrm{C}}$ & $0.1 \pm 0.0^{\mathrm{C}}$ \\
\hline & $7.5-20$ & $6.7 \pm 1.1^{\mathrm{A}}$ & $0.3 \pm 0.1^{\mathrm{A}}$ & $0.2 \pm 0.1^{\mathrm{B}}$ & $5.5 \pm 1.6^{\mathrm{C}}$ & $0.1 \pm 0.1^{\mathrm{C}}$ & $0.1 \pm 0.0^{\mathrm{B}}$ \\
\hline & $20-40$ & $6.4 \pm 1.0^{\mathrm{B}}$ & $0.3 \pm 0.1^{\mathrm{A}}$ & $0.1 \pm 0.1^{\mathrm{A}}$ & $4.9 \pm 1.6^{\mathrm{C}}$ & $0.1 \pm 0.0^{\mathrm{B}}$ & $0.1 \pm 0.1^{\mathrm{C}}$ \\
\hline \multirow{4}{*}{$\mathbf{T} 2$} & $0-2.5$ & $7.5 \pm 1.8^{\mathrm{B}}$ & $0.4 \pm 0.1^{\mathrm{B}}$ & $442.0 \pm 129.0^{\mathrm{A}}$ & $60.0 \pm 15.6^{\mathrm{A}}$ & $2.2 \pm 0.8^{\mathrm{A}}$ & $0.7 \pm 0.1^{\mathrm{A}}$ \\
\hline & $2.5-7.5$ & $7.3 \pm 1.6^{\mathrm{B}}$ & $0.4 \pm 0.1^{\mathrm{BC}}$ & $99.2 \pm 55.0^{\mathrm{A}}$ & $63.7 \pm 21.6^{\mathrm{A}}$ & $1.1 \pm 0.2^{\mathrm{A}}$ & $0.4 \pm 0.1^{\mathrm{A}}$ \\
\hline & $7.5-20$ & $7.3 \pm 1.7^{\mathrm{A}}$ & $0.4 \pm 0.1^{\mathrm{A}}$ & $114.5 \pm 102.5^{\mathrm{A}}$ & $62.2 \pm 14.6^{\mathrm{A}}$ & $0.7 \pm 0.3^{\mathrm{A}}$ & $0.4 \pm 0.1^{\mathrm{A}}$ \\
\hline & $20-40$ & $7.0 \pm 1.2^{\mathrm{B}}$ & $0.4 \pm 0.1^{\mathrm{A}}$ & $69.9 \pm 57.4^{\mathrm{A}}$ & $62.2 \pm 18.9^{\mathrm{A}}$ & $0.7 \pm 0.3^{\mathrm{A}}$ & $0.4 \pm 0.1^{\mathrm{A}}$ \\
\hline \multirow{4}{*}{ T3 } & $0-2.5$ & $12.4 \pm 3.0^{\mathrm{A}}$ & $0.7 \pm 0.1^{\mathrm{A}}$ & $13.0 \pm 7.2^{\mathrm{C}}$ & $53.3 \pm 14.6^{\mathrm{A}}$ & $1.1 \pm 0.1^{\mathrm{B}}$ & $0.5 \pm 0.1^{\mathrm{B}}$ \\
\hline & $2.5-7.5$ & $11.1 \pm 2.6^{\mathrm{A}}$ & $0.5 \pm 0.1^{\mathrm{A}}$ & $13.1 \pm 13.0^{\mathrm{B}}$ & $32.3 \pm 9.0^{\mathrm{B}}$ & $0.7 \pm 0.3^{\mathrm{B}}$ & $0.2 \pm 0.1^{\mathrm{B}}$ \\
\hline & $7.5-20$ & $7.8 \pm 1.8^{\mathrm{A}}$ & $0.4 \pm 0.1^{\mathrm{A}}$ & $18.4 \pm 11.3^{\mathrm{B}}$ & $23.1 \pm 8.6^{\mathrm{B}}$ & $0.9 \pm 0.3^{\mathrm{A}}$ & $0.1 \pm 0.0^{\mathrm{B}}$ \\
\hline & $20-40$ & $7.3 \pm 0.9^{\mathrm{B}}$ & $0.4 \pm 0.1^{\mathrm{A}}$ & $7.5 \pm 6.2^{\mathrm{A}}$ & $20.4 \pm 14.6^{\mathrm{BC}}$ & $0.7 \pm 0.4^{\mathrm{A}}$ & $0.1 \pm 0.0^{\mathrm{BC}}$ \\
\hline \multirow{4}{*}{$\mathbf{T 4}$} & $0-2.5$ & $15.0 \pm 2.1^{\mathrm{A}}$ & $0.7 \pm 0.1^{\mathrm{A}}$ & $124.6 \pm 55.1^{\mathrm{B}}$ & $64.0 \pm 17.1^{\mathrm{A}}$ & $2.5 \pm 0.8^{\mathrm{A}}$ & $0.9 \pm 0.2^{\mathrm{A}}$ \\
\hline & $2.5-7.5$ & $10.4 \pm 2.2^{\mathrm{A}}$ & $0.5 \pm 0.1^{\mathrm{AB}}$ & $93.1 \pm 86.4^{\mathrm{A}}$ & $45.0 \pm 15.3^{\mathrm{B}}$ & $0.9 \pm 0.4^{\mathrm{AB}}$ & $0.4 \pm 0.1^{\mathrm{A}}$ \\
\hline & $7.5-20$ & $9.1 \pm 2.2^{\mathrm{A}}$ & $0.4 \pm 0.1^{\mathrm{A}}$ & $10.5 \pm 7.2^{\mathrm{B}}$ & $32.6 \pm 8.8^{\mathrm{B}}$ & $0.6 \pm 0.2^{A}$ & $0.1 \pm 0.1^{\mathrm{B}}$ \\
\hline & $20-40$ & $8.9 \pm 1.4^{\mathrm{A}}$ & $0.4 \pm 0.1^{\mathrm{A}}$ & $10.4 \pm 9.8^{\mathrm{A}}$ & $37.9 \pm 13.3^{\mathrm{B}}$ & $0.6 \pm 0.2^{\mathrm{A}}$ & $0.2 \pm 0.0^{\mathrm{B}}$ \\
\hline
\end{tabular}

Mean of 6 samples $( \pm \mathrm{SD}$ ); mean values followed by the same letters did not differ between the treatments at $\mathrm{p}>0.05$ based on Duncan's test. 
Table 4. Photosynthetic characteristics of Dipteryx odorata and Inga edulis in a degraded area under various fertilization treatments: net photosynthetic rate $\left(P_{\mathrm{n}}\right)$, dark respiration $\left(R_{\mathrm{d}}\right)$, stomatal conductance $\left(g_{\mathrm{s}}\right)$, transpiration rate $(E)$, maximum photochemical efficiency $\left(\mathrm{F}_{\mathrm{v}} / \mathrm{F}_{\mathrm{m}}\right)$ and performance index $\left(\mathrm{PI}_{\mathrm{ABS}}\right)$. T1 = no fertilization, $\mathrm{T} 2=$ chemical fertilization, $\mathrm{T} 3=$ green fertilization, $\mathrm{T} 4$ = green and chemical fertilization.

\begin{tabular}{|c|c|c|c|c|c|c|c|}
\hline \multirow{3}{*}{ Species } & \multirow{3}{*}{ Fertilization } & \multicolumn{6}{|c|}{ Parameter } \\
\hline & & $P_{\mathrm{n}}$ & $R_{\mathrm{d}}$ & $g_{\mathrm{s}}$ & $E$ & $\mathrm{~F}_{\mathrm{v}} / \mathrm{F}_{\mathrm{m}}$ & $\mathrm{PI}_{\mathrm{ABS}}$ \\
\hline & & \multicolumn{2}{|c|}{$\left[\mu \mathrm{mol} \cdot \mathrm{m}^{-2} \cdot \mathrm{s}^{-1}\right]$} & \multicolumn{2}{|c|}{$\left[\mathrm{mmol} \cdot \mathrm{m}^{-2} \cdot \mathrm{s}^{-1}\right]$} & & \\
\hline \multirow{4}{*}{ Dipteryx odorata } & $\mathrm{T} 1$ & $7.6 \pm 2.5^{\mathrm{Bb}}$ & $1.0 \pm 0.3^{\mathrm{Ab}}$ & $144 \pm 65^{\mathrm{Ab}}$ & $2.9 \pm 1.2^{\mathrm{Ab}}$ & $0.69 \pm 0.03^{\mathrm{Ba}}$ & $1.2 \pm 1.1^{\mathrm{Aa}}$ \\
\hline & $\mathrm{T} 2$ & $11.0 \pm 1.9^{\mathrm{Ab}}$ & $0.6 \pm 0.4^{\text {Аа }}$ & $187 \pm 80^{\mathrm{Ab}}$ & $3.5 \pm 1.2^{\mathrm{Ab}}$ & $0.75 \pm 0.03^{\mathrm{Aa}}$ & $2.0 \pm 1.4^{\mathrm{Aa}}$ \\
\hline & $\mathrm{T} 3$ & $11.4 \pm 2.7^{\mathrm{Ab}}$ & $0.7 \pm 0.4^{\mathrm{Ab}}$ & $205 \pm 59^{\mathrm{Ab}}$ & $3.2 \pm 1.4^{\mathrm{Ab}}$ & $0.75 \pm 0.04^{\mathrm{ABa}}$ & $1.3 \pm 0.7^{\mathrm{Ab}}$ \\
\hline & $\mathrm{T} 4$ & $13.1 \pm 2.4^{\mathrm{Ab}}$ & $0.5 \pm 0.3^{\mathrm{Ab}}$ & $220 \pm 76^{\mathrm{Ab}}$ & $3.9 \pm 0.9^{\mathrm{Ab}}$ & $0.74 \pm 0.05^{\mathrm{ABa}}$ & $2.9 \pm 1.8^{\mathrm{Aa}}$ \\
\hline \multirow{4}{*}{ Inga edulis } & $\mathrm{T} 1$ & $12.1 \pm 3.1^{\mathrm{Ca}}$ & $2.4 \pm 0.7^{\mathrm{Aa}}$ & $340 \pm 76^{\mathrm{Ca}}$ & $5.3 \pm 0.8^{\mathrm{Ca}}$ & $0.59 \pm 0.05^{\mathrm{Bb}}$ & $0.5 \pm 0.5^{\mathrm{Ba}}$ \\
\hline & $\mathrm{T} 2$ & $16.8 \pm 0.7^{\mathrm{Ba}}$ & $1.1 \pm 0.2^{\mathrm{Ba}}$ & $383 \pm 67^{\mathrm{Ca}}$ & $5.8 \pm 0.5^{\mathrm{BCa}}$ & $0.77 \pm 0.03^{\text {Аa }}$ & $2.7 \pm 1.6^{\mathrm{ABa}}$ \\
\hline & $\mathrm{T} 3$ & $18.9 \pm 1.9^{\mathrm{Aba}}$ & $1.5 \pm 0.2^{\mathrm{Ba}}$ & $512 \pm 70^{\mathrm{Ba}}$ & $7.1 \pm 0.6^{\mathrm{ABa}}$ & $0.77 \pm 0.02^{\mathrm{Aa}}$ & $4.3 \pm 3.0^{\mathrm{Aa}}$ \\
\hline & $\mathrm{T} 4$ & $20.6 \pm 2.7^{\mathrm{Aa}}$ & $1.4 \pm 0.6^{\mathrm{Ba}}$ & $642 \pm 74^{\mathrm{Aa}}$ & $7.6 \pm 0.4^{\mathrm{Aa}}$ & $0.76 \pm 0.02^{\mathrm{Aa}}$ & $5.2 \pm 2.8^{\mathrm{Aa}}$ \\
\hline
\end{tabular}

Mean of 5 plants ( \pm SD); mean values followed by the same letters did not differ between the treatments at p $>0.05$ based on Duncan's test. Uppercase letters compare different fertilization treatments for each species, and lowercase letters compare the 2 species within the same fertilization treatment.

values of $g_{\mathrm{s}}$ varied between 144 and $220 \mathrm{mmol} \cdot \mathrm{m}^{-2} \cdot \mathrm{s}^{-1}$ in D. odorata (Table 4). I. edulis showed the highest $g_{\mathrm{s}}$ values in the treatments with green fertilization, reaching $642 \mathrm{mmol} \cdot \mathrm{m}^{-2} \cdot \mathrm{s}^{-1}$ in $\mathrm{T} 4$, which showed an increase of 88\% compared with T1. $I$. edulis showed higher $g_{\mathrm{s}}$ values than D. odorata in all fertilization treatments.

For $I$. edulis, the treatments with the highest values of $E$ were T3 and T4, reaching $7.6 \mathrm{mmol} \cdot \mathrm{m}^{-2} \cdot \mathrm{s}^{-1}$ in T4 with the lowest levels in T1. I. edulis had higher values of $E$ than D. odorata in all treatments (Table 4).

Significant effects of fertilization and species were observed for all parameters, but interaction between the factors occurred only for stomatal conductance (Table 2).

The high availability of nutrients in the soil in T2, T3 and T4 (Table 3), especially those nutrients related to the photosynthetic system ( $\mathrm{N}, \mathrm{P}, \mathrm{Ca}$ and $\mathrm{Mg}$ ) [12], is certain to represent one of the principal causes of the increase in $P_{\mathrm{n}}$ for both studied species. Our results also suggest that enhanced photosynthesis may play a role in the increased growth of tree seedlings and the incorporation of high biomass [33], all of which are of great interest to forest plantations, especially for the restoration of degraded areas [3] [4] [34].

The decrease of photosynthesis, as observed in T1, may be due to the combination of several stress factors, such as high irradiance and the lower availability and absorption of the essential nutrients for optimal functioning of the photosynthetic apparatus [35]. A nutritional deficiency, especially of $\mathrm{N}$, P and $\mathrm{K}$, has been found to produce a substantial decrease in photosynthetic rates under conditions of high irradiance related to low levels of chlorophyll, low structural integrity of chloroplasts, reduction in stomatal conductance, decreased activity of the enzyme ribulose-1,5-bisphosphate carboxylase/oxygenase (Rubisco) and the transport of photosynthates [9] [36].

Plant respiration may increase under high temperature and irradiance [37] due to the cost of the maintenance of cells, tissues and the photosynthetic apparatus, in addition to the investment in photoprotection mechanisms such as carotenoids [38]. In addition to K, Ca plays an important role in the process of stomatal closure through changes in the concentrations in the cytosol of guard cells in response to external stimuli such as biotic and abiotic stress [12] [39]. This mechanism, also explains the improved acclimation of both study species in the fertilization treatments.

Marenco et al. [37], working on plantations with tropical species in full-sunlight conditions, determined a value of $P_{\mathrm{n}}\left(8.7 \mu \mathrm{mol} \cdot \mathrm{m}^{-2} \cdot \mathrm{s}^{-1}\right)$ for $D$. odorata near those found in the present study in T1 $\left(7.5 \mu \mathrm{mol} \cdot \mathrm{m}^{-2} \cdot \mathrm{s}^{-1}\right)$. Similar values were also found for the other parameters, such as $R_{\mathrm{d}}, g_{\mathrm{s}}$ and $E$. Additionally, the high $g_{\mathrm{s}}$ and $E$ values observed in the green fertilization treatments (T3 and T4), in particular for I. edulis, support the hypothesis that the improvement of the chemical parameters of the soil may also be accompanied by improvements in physical parameters, especially water availability, obtained via fertilization with fresh plant material [19]. 


\subsection{Chlorophyll $a$ Fluorescence}

For $\mathrm{F}_{\mathrm{v}} / \mathrm{F}_{\mathrm{m}}$, the lowest values were found for I. edulis in T1 (0.59) (Table 4). Significant differences between the two species were observed only in $\mathrm{T} 1$. The highest values of $\mathrm{PI}_{\mathrm{ABS}}$ were found for I. edulis in $\mathrm{T} 4$ (Table 4). The lowest values for the same parameter were observed in $\mathrm{T} 1$ for both species (Table 4).

Significant effects on $\mathrm{PI}_{\mathrm{ABS}}$ were found for both factors, but no effects were observed in either species for $\mathrm{F}_{\mathrm{v}} / \mathrm{F}_{\mathrm{m}}$ (Table 2).

The values of $\mathrm{F}_{\mathrm{v}} / \mathrm{F}_{\mathrm{m}}$ found for $D$. odorata in $\mathrm{T} 2$, T3 and $\mathrm{T} 4$ in our study are similar to those reported by Gonçalves et al. [40] in conditions of full sunlight, by Gonçalves et al. [7] in a mixed stand under contrasting light conditions and by Morais et al. [41] in a 10-year-old mixed forest plantation near the Manaus region. Similar values of $\mathrm{F}_{\mathrm{v}} / \mathrm{F}_{\mathrm{m}}$ were found by Santos Junior et al. [4] for I. edulis 2 months after planting during the restoration of a degraded area damaged by oil-retrieval activity in the Amazon. The $\mathrm{F}_{\mathrm{v}} / \mathrm{F}_{\mathrm{m}}$ ratio has been used as a stress indicator in many photosynthetic studies [16] [17] [42].

The performance index $\left(\mathrm{PI}_{\mathrm{ABS}}\right)$ is a more responsive parameter, having a higher sensitivity than $\mathrm{F}_{\mathrm{v}} / \mathrm{F}_{\mathrm{m}}$ alone, because it relates energy trapping and dissipation events and electron transport-efficiency components that appear to be very sensitive to different stresses. This parameter has been very useful for physiological and environmental studies [17] [18] [40] [43]. T4 produced higher values of $\mathrm{PI}_{\mathrm{ABS}}$ for the two species by improving their nutritional status and, presumably, physical soil properties such as higher soil moisture [19]. The increased nutrient availability in the soil (Table 3) may also be responsible for promoting better harvesting and trapping of the energy flux. For I. edulis, $\mathrm{PI}_{\mathrm{ABs}}$ was 11 times greater in $\mathrm{T} 4$ than in $\mathrm{T} 1$.

\subsection{Chloroplast Pigments}

For D. odorata, the values of chlorophyll $a$ (Chla) were 0.83 and $1.35 \mu \mathrm{mol} \mathrm{g}^{-1}$ for $\mathrm{T} 1$ and T2, respectively, an increase of 63\% (Table 5). The Chla content in I. edulis increased 100\% in T4 compared with T1. The same behavior was observed for chlorophyll $b$ (Chlb) in both species (Table 5).

The highest concentrations of carotenoids (Car) were found in T3 for D. odorata and in T2 for I. edulis (Table 5). D. odorata showed the highest values of the Chl $(a+b) / C a r$ ratio in T2 and T4, whereas I. edulis exhibited the best performance for this same parameter in $\mathrm{T} 4$.

Significant effects of the fertilization treatments were observed for Chla, Chlb, Car and Chl $(a+b)$, but no differences were found between the species for the same parameters, nor were there interactions between the factors (Table 2).

Table 5. Chloroplast pigment concentrations on a leaf fresh-mass basis in Dipteryx odorata and Inga edulis in all of the fertilization treatments: chlorophyll $a(\mathrm{Chl} a)$, chlorophyll $b(\mathrm{Chl} b)$, carotenoids (Car), chlorophyll $(a+b)(\mathrm{Chl}(a+b))$, chlorophyll $a / b(\mathrm{Chl} a / \mathrm{Chl} b)$ and chlorophyll $(a+b) /$ carotenoids $(\mathrm{Chl}(\mathrm{a}+\mathrm{b}) / \mathrm{Car}) . \mathrm{T} 1=$ no fertilization, $\mathrm{T} 2=$ chemical fertilization, $\mathrm{T} 3$ = green fertilization, $\mathrm{T} 4=$ green and chemical fertilization .

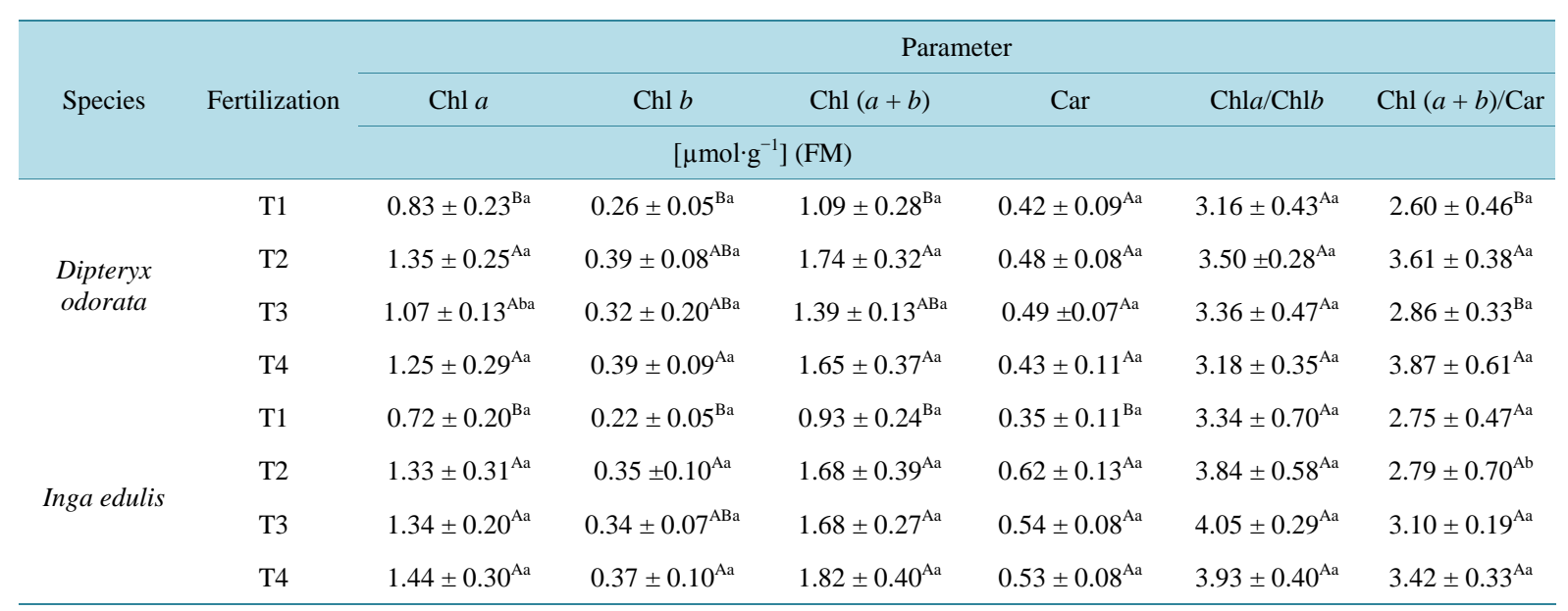

Mean of 5 plants $( \pm \mathrm{SD})$; mean values followed by the same letters did not differ between the treatments at p > 0.05 based on Duncan’s test. Uppercase letters compare different fertilization treatments for each species, and lowercase letters compare the 2 species within the same fertilization treatment. 
An increase in the Chla/Chlb ratio results in better energy absorption and may be considered to indicate a decrease in the stress caused by excess irradiance [42] [44]. The lowest values of the Chla/Chlb ratio were found in T1 for both D. odorata and I. edulis. The presence of N, especially in the molecules of chlorophyll and Rubisco, is essential for the full functioning of the photosynthetic apparatus [45]. Mg is an important component of the chlorophyll and primary-ion balance involved in photosynthesis [46]. The increase in the $\mathrm{N}$ and $\mathrm{Mg}$ supply found in T2, T3 and T4 (Table 3) also contributed to the high values of chlorophyll content observed in the fertilization treatments.

Carotenoids are a component of the light-harvesting antenna of the photosystems in the thylakoid membranes and are, thus, essential for the photoprotection of the photosynthetic apparatus [8] [18]. The Chl $(a+b) / C a r$ ratio has been used as an indicator of possible photooxidative damage, with the highest values suggesting a better adaptation to high irradiance [47]. As noted above, the highest values of the Chl $(a+b) / C a r$ ratio were found in T4 for both species, showing a better adaptation of these species under fertilization.

\section{Conclusion}

In terms of the hypothesis tested in this study, our results suggest that the combination of green and chemical fertilization was more effective in improving the photosynthetic performance and the growth of both species during initial establishment in a degraded area than either treatment alone. Finally, as expected, the species $I$. edulis showed better performance in the fertilization treatments because it is a rapid growing and early successional species.

\section{Acknowledgements}

The authors thank the National Institute of Amazonian Research (MCTI-INPA) for logistical support and the Balbina power plant for providing the experimental area and assistance from the staff. The authors also thank CAPES and CNPq for fellowships and funding for this research. JFC Gonçalves and CF de Lacerda are researchers with the Brazilian Council for Research and Development (CNPq).

\section{References}

[1] Davidson, E.A., Araujo, A.C., Artaxo, P., Balch, J.K., Brown, I.F., Bustamante, M.M.C., Coe, M.T., Defries, R.S., Keller, M., Longo, M., Munger, J.W., Schroeder, W., Soares-Filho, B.S., Souza Jr., C.M. and Wofsy, S.C. (2012) Amazon Basin in Transition. Nature, 481, 321-328. http://dx.doi.org/10.1038/nature10717

[2] Parrotta, J.A., Turnbull, J.W. and Jones, N. (1997) Catalyzing Native Forest Regeneration on Degraded Tropical Lands. Forest Ecology and Management, 99, 1-7. http://dx.doi.org/10.1016/S0378-1127(97)00190-4

[3] Gonçalves, J.F.C. and Santos Jr., U.M. (2005) Utilization of the Chlorophyll a Fluorescence Technique as a Tool for Selecting Tolerant Species to Environments of High Irradiance. Brazilian Journal of Plant Physiology, 17, 307-313. http://dx.doi.org/10.1590/S1677-04202005000300005

[4] Santos Jr., U.M., Gonçalves, J.F.C. and Feldpausch, T.R. (2006) Growth, Leaf Nutrient Concetration and Photosynthetic Nutrient Use Efficiency in Tropical Tree Species Planted in Degraded Areas in Central Amazonia. Forest Ecology and Management, 226, 299-309. http://dx.doi.org/10.1016/j.foreco.2006.01.042

[5] Ciccarese, L., Mattsson, A. and Pettenella, D. (2012) Ecosystem Services from Forest Restoration: Thinking Ahead. New Forests, 43, 543-560. http://dx.doi.org/10.1007/s11056-012-9350-8

[6] Silva, C.E.M., Gonçalves, J.F.C. and Feldpausch, T.R. (2008) Water-Use Efficiency of Trees Species Following Calcium and Phosphorus Application on an Abandoned Pasture, Central Amazonia, Brazil. Environmental and Experimental Botany, 64, 189-195. http://dx.doi.org/10.1016/j.envexpbot.2008.03.001

[7] Gonçalves, J.F.C., Marenco, R.A. and Vieira, G. (2001) Concentration of Photosynthetic Pigments and Chlorophyll Fluorescence of Mahogany and Tonka Bean under Two Light Environments. Brazilian Journal of Plant Physiology, 13, 149-157.

[8] Müller, P., Li, X. and Niyogi, K.K. (2001) Non-Photochemical Quenching. A Response to Excess Light Energy. Plant Physiology, 125, 1558-1566. http://dx.doi.org/10.1104/pp.125.4.1558

[9] Cakmak, I. (2005) The Role of Potassium in Alleviating Detrimental Effects of Abiotic Stresses in Plants. Journal of Plant Nutrition and Soil Science, 168, 521-530. http://dx.doi.org/10.1002/jpln.200420485

[10] Sunkar, R., Chinnusamy, V., Zhu, J. and Zhu, J. (2007) Small RNAs as Big Players in Plant Abiotic Stress Responses and Nutrient Deprivation. Trends in Plant Science, 12, 301-309. http://dx.doi.org/10.1016/j.tplants.2007.05.001 
[11] Ashraf, M. and Harris, P.J.C. (2013) Photosynthesis under Stressful Environments: An Overview. Photosynthetica, 51, 163-190. http://dx.doi.org/10.1007/s11099-013-0021-6

[12] Maathuis, F.J.M. (2009) Physiological Functions of Mineral Macronutrients. Current Opinion in Plant Biology, 12, 250-258. http://dx.doi.org/10.1016/j.pbi.2009.04.003

[13] Pasquini, S.C. and Santiago, L.S. (2012) Nutrients Limit Photosynthesis in Seedlings of a Lowland Tropical Forest Tree Species. Oecologia, 168, 311-319. http://dx.doi.org/10.1007/s00442-011-2099-5

[14] Adams, M.A., Simon, J. and Pfautsch, S. (2010) Woody Legumes: A (Re)view from the South. Tree Physiology, 30, 1072-1082. http://dx.doi.org/10.1093/treephys/tpq061

[15] Cooke, S.J. and Suski, C.D. (2008) Ecological Restoration and Physiology: An Overdue Integration. BioScience, 58, 957-968. http://dx.doi.org/10.1641/B581009

[16] Parker, W.C. and Mohammed, G.H. (2000) Photosynthetic Acclimation of Shade-Grown Red Pine (Pinusresinosa Ait.) Seedlings to a High Light Environment. New Forests, 19, 1-11. http://dx.doi.org/10.1023/A:1006668928091

[17] Stirbet, A. and Govindjee (2011) On the Relation between the Kautsky Effect (Chlorophyll a Fluorescence Induction) and Photosystem II: Basics and Applications of the OJIP Fluorescence Transient. Journal of Photochemistry and Photobiology B: Biology, 104, 236-257. http://dx.doi.org/10.1016/j.jphotobiol.2010.12.010

[18] Kalaji, H.M., Carpentier, R., Allakhverdiev, S.I. and Bosa, K. (2012) Fluorescence Parameters as Early Indicators of Light Stress in Barley. Journal of Photochemistry and Photobiology B: Biology, 112, 1-6. http://dx.doi.org/10.1016/j.jphotobiol.2012.03.009

[19] Ferreira, M.J., Gonçalves, J.F.C. and Ferraz, J.B.S. (2009) Photosynthetic Parameters of Young Brazil Nut (Bertholletia excelsa H. B.) Plants Subjected to Fertilization in a Degraded Area in Central Amazonia. Photosynthetica, 47, 616620. http://dx.doi.org/10.1007/s11099-009-0088-2

[20] de Faria, S.M., Abdala, G.D., Lima, A.C., Ribeiro, R.D., Galiana, A., Castilho, A.F. and Henriques, J.C. (2010) Evaluating the Nodulation Status of Leguminous Species from the Amazonian Forest of Brazil. Journal of Experimental Botany, 61, 3119-3127. http://dx.doi.org/10.1093/jxb/erq142

[21] Lojka, B., Dumas, L., Preininger, D., Polesny, Z. and Banout, J. (2010) The Use and Integration of Inga edulis in Agroforestry Systems in the Amazon-Review Article. Agricultura Tropicaet Subtropica, 43, 352-359.

[22] Fearnside, P.M. and Leal Filho, N.L. (2001) Soil and Development in Amazonia: Lessons from the Biological Dynamics of Forest Fragments Project. In: Bierregaard, R.O., Gascon, C., Lovejoy, T.E. and Mesquita, R., Eds., Lessons from Amazonia: The Ecology and Conservation of a Fragmented Forest, Yale University Press, New Haven, 291-312.

[23] Hunt, R. (1990) Basic Growth Analysis. Edward Arnold, London. http://dx.doi.org/10.1007/978-94-010-9117-6

[24] Lichtenthaler, H.K. and Wellburn, A.R. (1983) Determination of Total Carotenoids and Chlorophylls a and b of Leaf Extracts in Different Solvents. Biochemical Society Transactions, 11, 591-603.

[25] Srivastava, A., Strasser, R.J. and Govindjee. (1999) Greening of Peas: Parallel Measurements of 77 K Emission Spectra, OJIP Chlorophyll a Fluorescence, Period Four Oscillation of the Initial Fluorescence Level, Delayed Light Emission, and P700. Photosynthetica, 37, 365-392. http://dx.doi.org/10.1023/A:1007199408689

[26] Hall, J.S., Love, B.E., Garen, E.J., Slusser, J.L., Saltonstall, K., Mathias, S., Breugel, M., Ibarra, D., Bork, E.W., Spaner, D., Wishnie, M.H. and Ashton, M.S. (2011) Tree Plantations on Farms: Evaluating Growth and Potential for Success. Forest Ecology and Management, 261, 1675-1683. http://dx.doi.org/10.1016/j.foreco.2010.09.042

[27] Joslin, A.H., Markewitz, D., Morris, L.A., Oliveira, F.A., Figueiredo, R.O. and Kato, O.R. (2011) Five Native Tree Species and Manioc under Slash-and-Mulch Agroforestry in the Eastern Amazon of Brazil: Plant Growth and Soil Responses. Agroforestry Systems, 81, 1-14. http://dx.doi.org/10.1007/s10457-010-9356-1

[28] Souza, C.R., Azevedo, C.P., Lima, R.M. and Rossi, L.M.B. (2010) Comportamento de Espécies Florestais em Plantios a Pleno Sol e em Faixas de Enriquecimento de Capoeira na Amazônia. ActaAmazonica, 40, 127-134. (In Portuguese) http://dx.doi.org/10.1590/S0044-59672010000100016

[29] Souza, C.R., Lima, R.M.B., Azevedo, C.P. and Rossi, L.M.B. (2008) Efficiency of Forest Species for Multiple Use in Amazonia. Scientia Forestalis, 36, 7-14.(In Portuguese)

[30] Tonini, H., Oliveira Jr., M.M.C. and Schwengber, D. (2008) Growth of Amazon Native Species Submitted to the Plantation in the Roraima State. Ciência Florestal, 18, 151-158. (In Portuguese)

[31] Nichols, J.D., Rosemeyer, M.E., Carpenter, F.L. and Kettler, J. (2001) Intercropping Legume Trees with Native Timber Trees Rapidly Restores Cover to Eroded Tropical Pasture without Fertilization. Forest Ecology and Management, 152, 195-209. http://dx.doi.org/10.1016/S0378-1127(00)00603-4

[32] Cherr, C.M., Scholberg, J.M.S. and McSoley, R. (2006) Green Manure Approaches to Crop Production: A Synthesis. Agronomy Journal, 98, 302-319. http://dx.doi.org/10.2134/agronj2005.0035

[33] Jaquetti, R.K. (2012) Initial Growth and Photosynthetic Responses of Three Leguminous Trees Subjected to Green and 
Chemical Fertilization in Forest Plantation in the Amazon. Dissertation, National Institute of Amazonian Research, Manaus. (In Portuguese)

[34] Ferreira, M.J., Gonçalves, J.F. and Ferraz, J.B.S. (2012) Growth and Water Use Efficiency of Young Brazil Nut Plants on Degraded Area Subjected to Fertilization. Ciencia Florestal, 22, 393-401. (In Portuguese)

[35] Mittler, R. (2006) Abiotic Stress, the Field Environment and Stress Combination. Trends in Plant Science, 11, 15-19. http://dx.doi.org/10.1016/j.tplants.2005.11.002

[36] Zhao, D.L., Oosterhuis, D.M. and Bednarz, C.W. (2001) Influence of Potassium Deficiency on Photosynthesis, Chlorophyll Content, and Chloroplast Ultrastructure of Cotton Plants. Photosynthetica, 39, 103-109. http://dx.doi.org/10.1023/A:1012404204910

[37] Marenco, R.A., Gonçalves, J.F.C. and Vieira, G. (2001) Leaf Gas Exchange and Carbohydrates in Tropical Trees Differing in Successional Status in Two Light Environments in Central Amazonia. Tree Physiology, 21, 1311-1318. http://dx.doi.org/10.1093/treephys/21.18.1311

[38] Clearwater, M.J., Susilawaty, R., Effendi, R. and van Gardingen, P.R. (1999) Rapid Photosynthetic Acclimation of Shorea johorensis Seedlings after Logging Disturbance in Central Kalimantan. Oecologia, 121, 478-488. http://dx.doi.org/10.1007/s004420050954

[39] McAinsh, M.R. and Pittman, J.K. (2009) Shaping the Calcium Signature. New Phytologist, 181, 275-294. http://dx.doi.org/10.1111/j.1469-8137.2008.02682.x

[40] Gonçalves, J.F.C., Silva, C.E., Guimarães, D.G. and Bernardes, R.S. (2010) Análise dos Transientes da Fluorescência da Clorofila a de Plantas Jovens de Carapa Guianensis e de Dipteryx odorata Submetidas a Dois Ambientes de Luz. Acta Amazonica, 40, 89-98. (In Portuguese) http://dx.doi.org/10.1590/S0044-59672010000100012

[41] de Morais, R.R., Gonçalves, J.F.C., Santos Júnior, U.M., Dünisch, O. and Santos, A.L.W. (2007) Chloroplastid Pigment Contents and Chlorophyll a Fluorescence in Amazonian Tropical Tree Species. Revista Árvore, 31, 959-966. http://dx.doi.org/10.1590/S0100-67622007000500020

[42] Krause, G.H., Koroleva, O.Y., Dalling, J.W. and Winter, K. (2001) Acclimation of Tropical Tree Seedlings to Excessive Light in Simulated Tree-Fall Gaps. Plant, Cell and Environment, 24, 1345-1352. http://dx.doi.org/10.1046/j.0016-8025.2001.00786.x

[43] Gonçalves, J.F.C., Santos Jr., U.M., Nina Jr., A.R. and Chevreuil, L.R. (2007) Energetic Flux and Performance Index in Copaiba (Copaifera multijuga Hayne) and Mahogany (Swietenia macrophylla King) Seedlings Grown under Two Irradiance Environments. Brazilian Journal of Plant Physiology, 19, 171-184. http://dx.doi.org/10.1590/S1677-04202007000300001

[44] Hallik, L., Niinemets, Ü. and Kull, O. (2012) Photosynthetic Acclimation to Light in Woody and Herbaceous Species: A Comparison of Leaf Structure, Pigment Content and Chlorophyll Fluorescence Characteristics Measured in the Field. Plant Biology, 14, 88-99.

[45] Makoto, K. and Koike, T. (2007) Effects of Nitrogen Supply on Photosynthetic and Anatomical Changes in CurrentYear Needles of Pinus koraiensis Seedlings Grown under Two Irradiances. Photosynthetica, 45, 99-104. http://dx.doi.org/10.1007/s11099-007-0015-3

[46] Liu, X., Ellsworth, D.S. and Tyree, M.T. (1997) Leaf Nutrition and Photosynthetic Performance of Sugar Maple (Acer saccharum) in Stands with Contrasting Health Conditions. Tree Physiology, 17, 169-178. http://dx.doi.org/10.1093/treephys/17.3.169

[47] Hendry, G.A.F. and Price, A.H. (1993) Stress Indicators: Chlorophylls and Carotenoids. In: Hendry, G.A.F. and Grime, J.P., Eds., Methods in Comparative Plant Ecology, Chapman \& Hall, London, 148-152. 


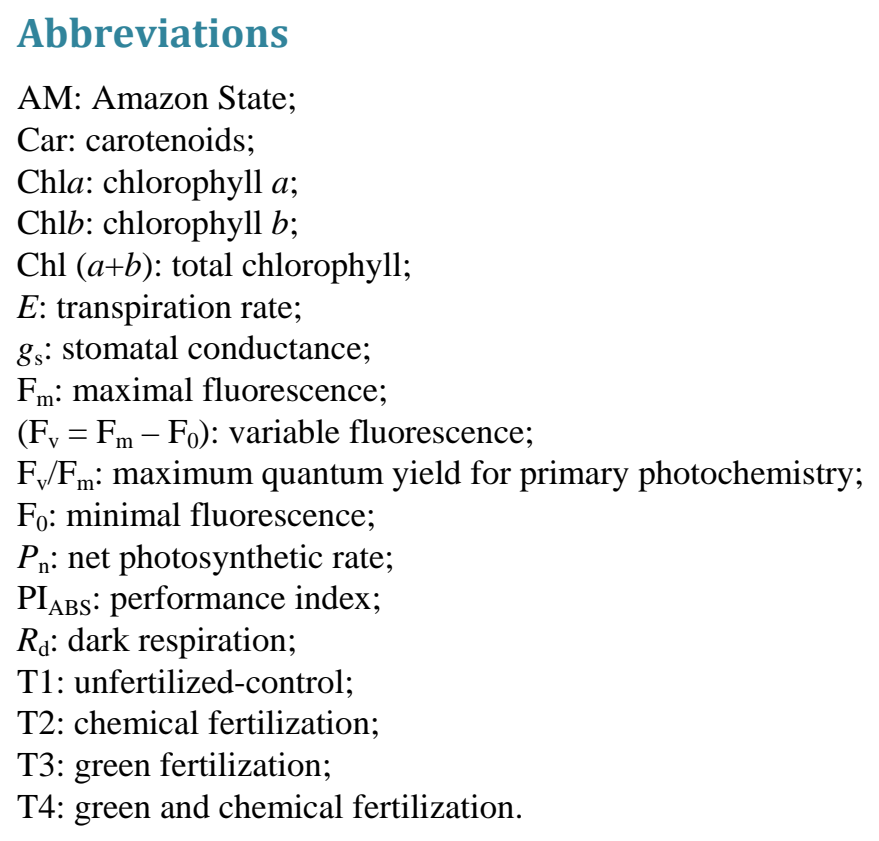


Scientific Research Publishing (SCIRP) is one of the largest Open Access journal publishers. It is currently publishing more than 200 open access, online, peer-reviewed journals covering a wide range of academic disciplines. SCIRP serves the worldwide academic communities and contributes to the progress and application of science with its publication.

Other selected journals from SCIRP are listed as below. Submit your manuscript to us via either submit@scirp.org or Online Submission Portal.
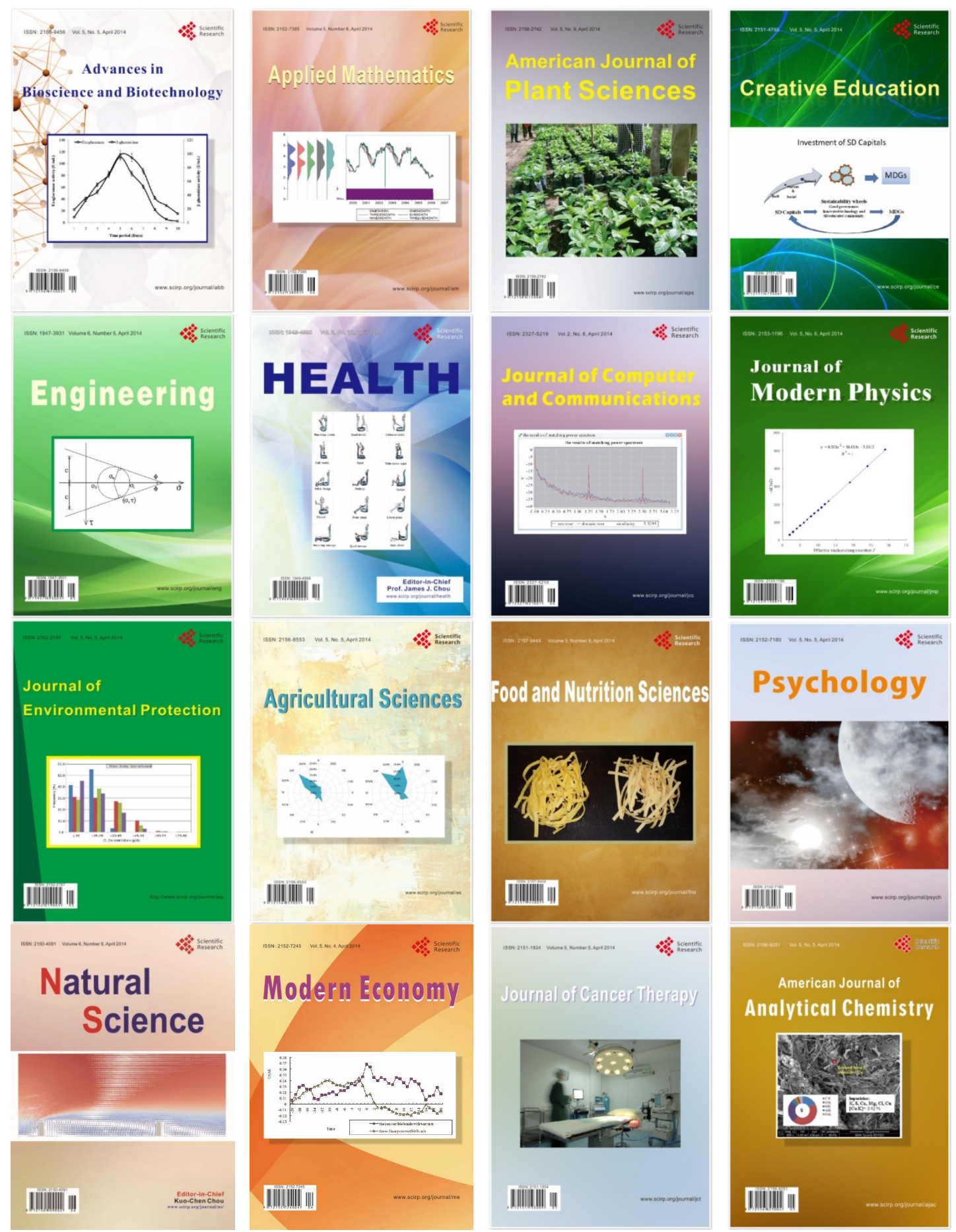